\title{
EFFECT OF HANDLING, MILLING PROCESS AND STORAGE ON THE QUALITY OF WHEAT AND FLOUR IN EGYPT: [1] PHYSICAL AND CHEMICAL PROPERTIES OF WHEAT KERNALS AND THEIR FLOURS.
}

Abd El Fadel, M.G.*; Seham S. Gad*; A. A. El-Shibiny*; M.F. Emara** and T.T. El-Sisy**

* Faculty of Environmental Agric. Sci. (Arish), Suez Canal University.

** Regional Center for Food and Feed, Agriculture Research Central.

\begin{abstract}
Six wheat kernels (Australian, Argentine, Ukrainian, American and Germany), and Egyptian wheat (Gamaza7) local wheat cultivars were subjected to physico-chemical properties. Results indicated that the Germany wheat grains had higher total physical defects. Flour yields were about $70 \%$ for all tested wheat samples except for the American soft red winter wheat and Ukrainian hard red wheat, which were as low as $65.0 \%$. A wide range of protein content $(9.60-11.50 \%)$ of flours was recorded. The Argentine soft red winter wheat flour had the highest protein content and the Australian stander white wheat flour was the lowest in protein content. Wet and dry gluten contents of wheat flour samples were consistent with their protein contents. Data indicated that Australian and Argentine, flours had more suitable properties for bread- making than the American and Egyptian flours. From the different tested wheat flours indicated that those made from Australian wheat, and Argentine wheat flours were superior.
\end{abstract}

Keywords: Wheat, Flour, Physical, chemical, properties, handling, milling, storage.

\section{INTRODUCTION}

Most wheat cultivar are grouped under the broad category of common or bread wheat' (Triticum aestivum), which accounts for approximately $95 \%$ of world production, and durum wheat (Triticum durum) used for pasta production (Peressini et al., 1999). In Egypt, 10.9 million tons of different wheat varieties are milled per year (2003 data). Millers buy wheat with a wide range of quality characteristics. About 4057234 tons $(37.2 \%)$ of imported wheats and 6844692 tons $(62.8 \%)$ of local wheats were used during the season of 2003 FAO, (2005). Most of these amounts are used for bread making, while the rest are used for other baked products and pasta production. Wheat grades are based on government standards. The grade standards include bushel weight, heat damage, foreign matter, broken kernels, and presence of wheat from other classes. D'Appolonia and Emeritus, (1996). Wheat grading is carried out by evaluating a representative sample from the whole quantity of wheat to check for off-odor and insects, determine dockage, test weight, defects and wheat of other classes. Optional analysis for protein determination, mycotoxins, falling numbers, and hardness are determined if specified. These grading procedures help to insure end users and consumers that they will receive consistent quality and sound wheat Harnza, (2003). Wheat flour is the major ingredient in many products 
and consequently it exerts a major effect on their quality. It is also a complex biological entity and, as such, varies significantly with the source of the wheat. As a complex system, and because it is obtained from a plant, wheat flour contains a multitude of compounds found in any living tissue. These include: moisture 14\%, proteins $7-15 \%$ (albumins, globulins, prolamin, glutelin), starch $63-72 \%$ (amylopectin, amylose), non starchy polysaccharides $4.5-5.0 \%$ (pentosans and beta glucans), lipids $1 \%$, as well as vitamins (thiamin, riboflavin, niacin) and minerals (iron, sodium, potassium, calcium, magnesium, copper, zinc). The most of these components play an important role in the way of how the flour-based and other product constituens will behave during processing or how the final product meets the consumer's requirements Katarina and Dušanka, (2008). Bread-making quality of a variety usually reacts like other quantitative characteristics to favourable or unfavourable environmental conditions and varies its performance. It is unrealistic to expect the same level of performance in all environments (Grausgruber et al., 2000). For the milling and baking industry, it is desirable that quality traits should be maintained as stable as possible through all environments. There exit different concepts of stability definition.

Many researcher reported that the comparison of different varieties mean test weight with wheat standards showed that all wheat grains were of premium quality Pasha, (2006), Nagarajan, (2005) which reported that the standard mill quality wheat, medium grain size and appearance, medium hard, dry gluten $9 \%$, protein $>10 \%,>\mathrm{HLW} 76$, seed moisture $11 \%$, total defects $6 \%$, extraction efficiency $<69 \%$ sedimentation value $<40$. Bold and lustrous grain, dry gluten $9 \%$, protein $>12 \%$, HLW approx. 80 , seed moisture $11 \%$; extraction efficiency is approx. $70 \%$. Pasha (2006) who reported the falling number ranged from $243-648$ in fifty different wheat varieties during 2004-05. (Gupta et al., 2002) reported that the wheat grain classification is essential for trade and quality control as the buyer is able to understand the utilities of the supply and negotiate a price. The approach rests on two parameters, namely the physical purity or "Grade" and the other grouping called "Class" which is based on the grain quality traits. Moisture content is dependent on genetic makeup of wheat varieties and is largely influenced by agronomic and climatic conditions Mahmood, (2004). Charles, (2005) who reported that protein content of hard red winter wheat ranges from $13 \%$ to $15 \%$, soft white winter from $10 \%$ to $12 \%$. The endosperm make up almost $83 \%$ of the kernel and contains $73 \%$ of the total protein. (Autio et al., 2001) found that the chemical composition of four different flour types were ranged from 13.3 to $14.2 \%$ for moisture, 11.8 to $14.2 \%$ for protein, 0.62 to $0.89 \%$ for ash and 27.2 to $3.7 \%$ for wet gluten. Wheat (Triticum aestivum L.) is one of the most important staple crops worldwide. Flour color is an important trait in the assessment of flour quality for the production of many end products (Kun$\mathrm{Pu}$ et al., 2009). D,Appolonia and Emeritus, (1996) who reported that damaged starch is created during milling. Higher damaged starch levels increase absorption and the amount of yeast fermentation. Milling separates the bran and germ fractions from the endosperm, which is used to make flour, and reduces endosperm particles to the correct size. 
The aim of research to evaluate the most common imported wheats (Australian, Argentine, Ukrainian, American and Germany), as well as a local wheat cultivars Egyptian wheat (Gamaza7) for bread - making. -The physical, chemical, rheological as well as the manufactured bread quality characteristics were examined.

\section{MATERIALS AND METHODS}

\section{Wheat samples.}

Five imported wheat grains (Triticum aestivum ) different cultivars were obtained from Argentine, Germany, Ukrainian, Australia and U.S.A which were obtained from five locations (Alexandria, Domiata, El-Suwas, ElSkhna and Cairo) and Egyptian wheat grains (Gamaza 7) were obtained from El-Ghrbia. They were taken from six different Companies since 2009.

\section{Preparation of wheat flours}

A twenty $\mathrm{kg}$ of each wheat sample used in this investigation was stored 90 days at temperature $25^{\circ} \mathrm{C}$ and relative humidity less than $62 \%$ and taken samples from stored wheat at different time $(0,7,14,21,30,36,42$, 49, 60, 66, 72, 84 and 90) According to the methods described in U.S. Department of Agriculture, (1995 A). At the end of stored wheat sample was cleaned mechanically to remove dirt, dockage, imparters and other strange grains by Carter Dockage Tester According to the methods described in U.S. Department of Agriculture, (2002 C). the wheat samples were tempered to $16.5 \%$ moisture and allowed to conditioning for 24 hours, than milled by Laboratory mill CD1 auto Chopin According to the methods described in AACC method (2000 A).the extraction rate of any flour sample was adjusted to recurred rate ( $72 \%$ extraction).

\section{Analytical methods \\ Physical properties}

Cleanliness, dockage, shrunken and broken, foreign materials, total damaged kernels and total defects were separated and determined manually (hand picking). Test weight pound per bushel, Test weight $\mathrm{P} / \mathrm{B}=(\mathrm{Kg} /$ Hectoliter) $\div 1.278$ according to U.S. Department of Agriculture, (2004 D). A thousand kernel weight was determined by counting the kernels in a $10 \mathrm{~g}$ wheat sample AACC method, $(2000 \mathrm{C})$. Wet and dry gluten, and falling number were determined according to A.O.AC., (2005)

\section{Chemical properties}

Moisture, crude protein, ash, crude fiber, fat were determined according to A.O.AC., (2005) and U.S. Department of Agriculture, (1999 B). The nitrogen free extract(N.F.E) was calculated by difference.

\section{Statistical analysis}

Data of three replicates were computed for the analysis of standard division (S.D) among the means were determined by Duncan's multiple range test using SAS programs SAS, (1999). 
Abd El Fadel, M.G. et al.

\section{RESULTS AND DISCUSSION}

\section{Physical and chemical properties of wheat kernels and their flours}

Chemical composition of different wheat kernels used in these study is given in Table (1) that wheat moisture content of different varieties ranged from (8.6 to 9.8) for all studied samples. Australian stander white wheat had the highest value while Egyptian soft white wheat had lowest value among all samples. As regards protein content, Argentine soft red winter wheat had the highest protein $(12.50 \%)$ followed by Egyptian soft white wheat $(11.40 \%)$, while Australian stander white wheat $(10.40 \%)$ had the lowest protein content. On other hand nitrogen free extracts (NFE)\% rang from $71.17 \%$ (Argentine soft red winter wheat) to $74.41 \%$ (Australian stander white wheat). Additionally Ukrainian hard red wheat was lower fat (1.30) than other samples while Ukrainian hard red wheat was lower in Ash content (1.20) in completely in other wheat. Ash content of all wheat varieties was found quite close to each other. However, highest ash content was observed in Egyptian soft white wheat $(2.20 \%)$. The ash content of flour is related to the amount of bran in the flour and therefore to flour yield. The results of fiber showed that Egyptian soft white wheat had significant highest value $(3.54 \%)$ while Australian stander white wheat had lowest value (2.18).

Table 1: proximate analysis for six different wheat kernels

\begin{tabular}{|l|c|c|c|c|c|c|}
\hline Wheat & ArW & GeW & UkW & AmW & AuW & ESW \\
\hline M.C\% & $9.0 \pm 0.5$ & $8.70 \pm 0.1$ & $9.40 \pm 0.1$ & $9.60 \pm 0.1$ & $9.80 \pm 0.07$ & $8.60 \pm 0.1$ \\
\hline Protein\% & $12.50 \pm 0.1$ & $11.0 \pm 1.0$ & $11.0 \pm 1.0$ & $10.90 \pm 0.1$ & $10.40 \pm 0.1$ & $11.40 \pm 0.1$ \\
\hline Fat \% & $1.74 \pm 0.01$ & $1.59 \pm 0.01$ & $1.30 \pm 1.0$ & $1.35 \pm 0.01$ & $1.77 \pm 0.01$ & $1.70 \pm 0.01$ \\
\hline Ash\% & $2.10 \pm 0.1$ & $1.60 \pm 0.1$ & $1.20 \pm 0.1$ & $2.10 \pm 0.1$ & $1.44 \pm 0.1$ & $2.20 \pm 0.1$ \\
\hline Fiber\% & $3.49 \pm 0.01$ & $3.16 \pm 0.01$ & $2.70 \pm 0.1$ & $2.93 \pm 0.58$ & $2.18 \pm 0.01$ & $3.54 \pm 0.01$ \\
\hline NFE\% & $71.17 \pm 0.01$ & $73.95 \pm 0.01$ & $74.40 \pm 0.1$ & $73.12 \pm 0.01$ & $74.41 \pm 0.01$ & $72.56 \pm 0.01$ \\
\hline $\begin{array}{l}\text { Total caloric } \\
\text { values\% }\end{array}$ & $358.14 \pm 0.01$ & $354.11 \pm 0.01$ & $353.3 \pm 0.1$ & $347.95 \pm 0.01$ & $355.17 \pm 0.01$ & $245.58 \pm 0.01$ \\
\hline
\end{tabular}

NFE = Nitrogen free extracts, ArW =Argentine Soft Red winter Wheat, GeW =Germany Soft Red Wheat, UkW Ukrainian Hard Red Wheat, AmW =American Soft Red Winter Wheat, AuW =Australian Stander White Wheat, ESW=Egyptian soft White Wheat (gamaza 7)

Mean value of physical properties of six different wheat kernel cultivars are presented in Table (2). Moisture content among all samples which was ranged from 8.6 to $9.8 \%$. the highest moisture content noticed for Australian stander white wheat while the lowest moisture content noticed for Egyptian soft white wheat (Gamaza7). It can be concluded that the test weight for all samples which ranged from 58.03 to 63.6 pound per bushel. The same trend were observed in test weight where Argentine soft red winter wheat the highest and followed by Australian stander white wheat, Germany hard red wheat, Egyptian soft white wheat, American soft red winter wheat and Ukrainian hard red wheat. More ever the foreign material among all samples ranged from 0.05 to $0.19 \%$, either Argentine soft red winter wheat have highest percentage of shrunken and broken kernels followed by Australian stander white wheat. For damage kernels which contest of heat damage and total damage, specially Argentine soft red winter wheat and 
Ukrainian hard red wheat which have highest total damage kernels percentage $(2.0 \%)$ while Egyptian soft white wheat (Gamaza7) have lowest percentage of total damage kernels $(0.93 \%)$. It can be noticed that the American soft red winter wheat, Australian stander white wheat and Egyptian soft white wheat haven't heat damage. More ever from the same table noticed that all sample are free from insect and ok odor. The Egyptian stander no. 1601/1986 and it's modification on 23/4/2002 has obligation that the dockage \% (first separated from sample) not exceed $1 \%$, foreign material $\%$ not exceed $1 \%$, total damage kernels \% (heat damage ,sprout damage, insect damage and mould damage kernels) not exceed than $4 \%$. However that difference between wheat samples, all wheat samples had grade one according to U.S department of agriculture, (2006 D).

Table 2: Grading of six different wheat kernel cultivars.

\begin{tabular}{|c|c|c|c|c|c|c|}
\hline Wheat & ArW & GeW & UkW & AmW & AuW & ESW \\
\hline M.C\% & $9.0 \pm 0.5$ & $8.70 \pm 0.1$ & $9.40 \pm 0.1$ & $9.60 \pm 0.1$ & $9.80 \pm 0.07$ & $8.60 \pm 0.1$ \\
\hline T.W p/b & $63.14 \pm 0.01$ & $61.95 \pm 0.01$ & $58.03 \pm 0.01$ & $60.30 \pm 0.1$ & $62.6 \pm 0.07$ & $61.55 \pm 0.01$ \\
\hline F.M\% & $0.05 \pm 0.01$ & $0.16 \pm 0.01$ & $0.19 \pm 0.01$ & $0.13 \pm 0.01$ & $0.08 \pm 0.01$ & $0.10 \pm 0.01$ \\
\hline Sh.\& B.N\% & $1.76 \pm 0.01$ & $0.72 \pm 0.01$ & $0.36 \pm 0.01$ & $0.52 \pm 0.01$ & $0.75 \pm 0.07$ & $0.48 \pm 0.01$ \\
\hline \begin{tabular}{|l|l|} 
K $\%$ & H.D \\
\end{tabular} & $0.10 \pm 0.1$ & $0.20 \pm 0.2$ & $0.10 \pm 0.7$ & Zero & Zero & Zero \\
\hline D.K\% & $2.0 \pm 1.0$ & $1.50 \pm 0.1$ & $2.0 \pm 1.0$ & $1.60 \pm 0.1$ & $1.30 \pm 0.1$ & $0.93 \pm 0.01$ \\
\hline Odor & Ok & Ok & Ok & Ok & Ok & Ok \\
\hline Insect & Free & Free & Free & Free & Free & Free \\
\hline Grade & 1 & 1 & 1 & 1 & 1 & 1 \\
\hline
\end{tabular}

T.W = Test weight, $\mathrm{p} / \mathrm{b}=$ Pound per Bushel (American unit), M.c = Moisture Content, F.M = Foreign Material, Sh. \& B.N = Shrunken \&Broken kernels, D.K = Damage Kernels, H.D = Heat Damage, T.D = Total Damage, ArW =Argentine Soft Red winter Wheat, GeW =Germany Soft Red Wheat, UkW =Ukrainian Hard Red Wheat, AmW =American Soft Red Winter Wheat, AuW =Australian Stander White Wheat, ESW=Egyptian soft White Wheat (gamaza 7)

Results in Table (3) showed that 1000 kernels wheat ranged from 33.5 to $45.2 \mathrm{gm}$. Argentine soft red winter wheat have highest value (45.2gm) while Ukrainian hard red wheat have lowest value(33.5gm). for addition the kernel colour in all samples are red wheat whereas Australian stander white wheat and Egyptian soft white wheat are white wheat. Additionally it showed that wet, dry gluten, hydration ratio and gluten index ranged from (18.3 to $25.3 \%)$, ( 8.1 to $12.7 \%)$, (1.57 to $2.12 \%$ ) and ( 57.5 to $84.5 \%$ ) receptivity. From same table thesis results showed that the highest wet and dry gluten was observed in Australian stander white wheat (33.1\% and $12.7 \%)$ whereas lowest value was observed in Egyptian soft white wheat (Gamaza7) samples. On the other hand American soft red winter wheat have highest gluten index moreover the other samples are different between that Australian stander white wheat and American soft red winter for the gluten properties. Falling which indicted enzyme activity of Alfa amylase. In case of falling number, Australian stander white wheat highest falling number $(445 \mathrm{sec}$.) and lowest enzyme activity. From Table (3) it can be concluded that Australian stander white wheat have the good quality for physical properties in all different wheat samples followed by Argentine soft red winter wheat, American soft red winter wheat, Ukrainian hard red wheat and Germany hard red wheat. 
Abd El Fadel, M.G. et al.

Table 3: physical properties of six different wheat kernels

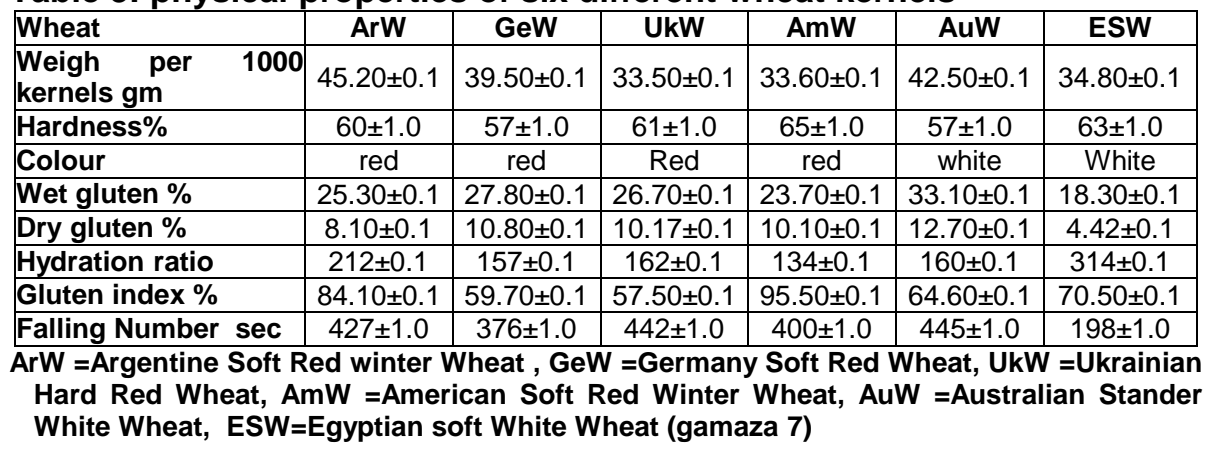

Results of Table (4) that the flour yield was different slightly among test samples and ranged from 64.3 to $69.8 \%$. So data present that Argentine soft red winter wheat had highest flour yield (69.8) while American soft red winter wheat and Ukrainian hard red wheat had lowest flour yield $(64.83 \%)$ and $(64.3 \%)$ receptivity on the other hand Ukrainian hard red wheat Had the highest coarse bran (18.26\%) while American soft red winter wheat, and Egyptian soft white wheat had lowest coarse bran (16.25\%). However American soft red winter wheat and Ukrainian hard red wheat had highest fin bran $(15.52 \%)$ and $(15.54 \%)$ receptivity while Egyptian soft white wheat had the lowest fin bran $(7.84 \%)$ and highest semolina (7.9\%). However, these differences may be partly attributed due to different growing and environmental conditions prevailed during growing periods (Randhawa et al., 2002).

Table 4: Extraction of different wheat flour obtained from six different wheat kernels

\begin{tabular}{|l|c|c|c|c|c|c|}
\hline \multicolumn{1}{|c|}{ Wheat Flour } & ArW & GeW & UkW & AmW & AuW & ESW \\
\hline Coarse Bran\% & 16.68 & 17.18 & 18.26 & 16.25 & 17.24 & 16.25 \\
\hline Fin Bran \% & 14.81 & 11.82 & 15.54 & 15.52 & 12.33 & 7.84 \\
\hline Semolina \% & 1.29 & 2.70 & 2.0 & 3.40 & 2.03 & 7.91 \\
\hline Flour yield \% & 69.80 & 68.30 & 64.20 & 64.83 & 68.40 & 68.0 \\
\hline
\end{tabular}

ArW =Argentine Soft Red winter Wheat, GeW =Germany Soft Red Wheat, UkW Ukrainian Hard Red Wheat, AmW =American Soft Red Winter Wheat, AuW =Australian Stander White Wheat, ESW=Egyptian soft White Wheat (gamaza 7)

Chemical composition of wheat flour prepared from different wheat kernels are showing from Table (5). Result indicted that chemical composition of flour are different in all investigated samples. Moisture content are ranged from $13.5 \%$ (American soft red winter wheat flour) to $13.85 \%$ (Argentine soft red winter wheat flour) while Argentine soft red winter wheat flour contain highest protein $(11.5 \%)$ and lower nitrogen free extract $(72.47 \%)$ than other samples, however Australian stander white wheat flour showed that have highest fat content compared with other studied samples. On other hand the American soft red winter wheat flour have a lower sample in ash. 
Table 5: proximate analysis of different wheat flour obtained from six different wheat kernels

\begin{tabular}{|c|c|c|c|c|c|c|}
\hline Wheat Flour & ArW & GeW & UkW & AmW & AuW & ESW \\
\hline M.C & 13.85 & 13.60 & 13.70 & 13.50 & 13.80 & 13.65 \\
\hline Protein \% & $11.50 \pm 0.1$ & $10.20 \pm 0.1$ & $9.80 \pm 0.1$ & $10.0 \pm 1.0$ & $9.60 \pm 0.1$ & $10.30 \pm 0.1$ \\
\hline Fat $\%$ & $1.20 \pm 0.1$ & $1.0 \pm 0.5$ & $1.15 \pm 0.01$ & $1.0 \pm 1.0$ & $1.22 \pm 0.01$ & $1.10 \pm 0.1$ \\
\hline Ash\% & $0.85 \pm 0.01$ & $0.50 \pm 0.1$ & $0.51 \pm 0.01$ & $0.48 \pm 0.01$ & $0.59 \pm 0.1$ & $0.90 \pm 0.1$ \\
\hline Fiber\% & $0.13 \pm 0.01$ & $0.15 \pm 0.01$ & $0.12 \pm 0.01$ & $0.11 \pm 0.01$ & $0.16 \pm 0.01$ & $0.20 \pm 0.1$ \\
\hline NFE\% & $72.47 \pm 0.3$ & $74.55 \pm 0.1$ & $74.72 \pm 0.01$ & $74.91 \pm 0.01$ & $74.63 \pm 0.16$ & $73.85 \pm 0.1$ \\
\hline $\begin{array}{l}\text { Total caloric } \\
\text { values } \%\end{array}$ & & $346.4 \pm 0.01$ & $347.23 \pm 0.01$ & $346.64 \pm 0.01$ & $347.1 \pm 0.01$ & $345.1 \pm 0.01$ \\
\hline
\end{tabular}

The data in Table (6) showed that the highest starch damage was in American soft red winter wheat flour $(4.59 \%)$ while Germany hard red wheat was lowest $(5.6 \%)$. The rheological properties wheat flour dough were tested by farinograph, alveograph and mixolab and the results shown wet and dry gluten and hydration ratio of different flour samples are given in Table (6). Results from Tables (5) and (6) indicated the increases in protein content wasn't accompanied by an increase in wet and dry gluten contents the Australian stander white wheat flour showed protein content of $9.60 \%$ have higher wet, dry gluten and hydration ratio than other samples 30, 9.60 and $213 \%$ respectively, while it had the lower protein content 9.6 than other samples. Additionally, all samples investigated have a good characteristics to production of bread except the Australian stander white wheat flour and Egyptian soft white wheat flour, while Australian stander white wheat flour it can be used for produce pasta and bread ,but the Egyptian soft white wheat flour it can be used for biscuits and breakfast food. The same table reviewed that the falling number values were ranged from 154 to $442 \mathrm{sec}$. Argentine soft red winter wheat flour had the highest value (442sec.) and the Egyptian soft white wheat flour had lower values (154sec.). Economic European community recommended that the falling number of flour should exceed than 230sec Milatovie and Mondelli, (1991). Egyptian stander no. 1419/2006 of white flour for production of bread has the following requirement: protein content not less than $10.2 \%$ Ash content not exceed than $0.9 \%$ And the falling number showed exceed than $200 \mathrm{Sec}$. Also, Egyptian stander no. $1649 / 2004$ for durum wheat has obligation that protein content of durum wheat not less than $10.5 \%$ and ash content not exceed than $1.3 \%$. From same Table (6) it can be concluded that the percentage of sediment ranged from 15 to $40 \%$. Australian stander white wheat flour was highest sediment ratio which had good characteristics for produce bread. At the end of the Table (6) it showed that white variety of wheat had the highest value of whiteness colour for flour colour (Egyptian soft white wheat flour and Australian stander white wheat flour) 39.9 and $38.5 \%$ than the red variety wheat which is less whiteness. Starch damaged are ranged from 4.59 to $5.6 \%$. Germany hard red wheat flour had the highest value while American Soft Red Winter Wheat flour had the lowest value. 
Abd El Fadel, M.G. et al.

Table 6: physicochemical properties of different wheat flour obtained from six different wheat kernels

\begin{tabular}{|c|c|c|c|c|c|c|c|}
\hline \multirow{2}{*}{\multicolumn{2}{|c|}{\begin{tabular}{|l} 
Wheat Flour \\
Starch damage \%
\end{tabular}}} & ArW & GeW & UkW & AmW & AuW & ESW \\
\hline & & 5.34 & 5.60 & 5.23 & 4.59 & 5.16 & 5.10 \\
\hline \multirow{4}{*}{ 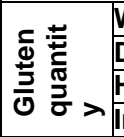 } & Wet\% & 25.30 & 25.0 & 24.30 & 20.0 & 30.0 & 20.40 \\
\hline & Dry\% & 8.10 & 8.0 & 7.77 & 6.40 & 9.60 & 6.52 \\
\hline & Hydration ratio & 2.12 & 2.13 & 2.08 & 2.13 & 2.13 & 2.12 \\
\hline & Index $\%$ & 93.40 & 92.60 & 90.70 & 83.50 & 93.30 & 80.10 \\
\hline \multicolumn{2}{|c|}{ Protein sediment \% } & 27 & 33 & 30 & 15 & 40 & 16 \\
\hline \multicolumn{2}{|c|}{ Falling Number Sec. } & $442 \pm 1.0$ & $360 \pm 1.0$ & $436 \pm 1.0$ & $383 \pm 1.0$ & $430 \pm 1.0$ & $154 \pm 1.0$ \\
\hline \multirow{2}{*}{$\begin{array}{l}\text { flour } \\
\text { Colour \% }\end{array}$} & White & 29.60 & 32.0 & 31.0 & 30.10 & 38.50 & 39.90 \\
\hline & $\%$ yellow & 17.10 & 15.80 & 15.20 & 16.30 & 14.0 & 12.80 \\
\hline
\end{tabular}

\section{Conclusion}

Data indicated that Australian and Argentine, flours had more suitable properties for bread- making than the American and Egyptian flours. From the different tested wheat flours indicated that those made from Australian wheat, and Argentine wheat flours were superior.

\section{REFERENCES}

AACC, (2000 A). American association of cereal chemists, Approved method of the AACC $10^{\text {th }}$ ed., vol. 1, AACC, St Paul, MN.

AACC, (2000 B). American association of cereal chemists, Approved method of the AACC $10^{\text {th }}$ ed., vol. 2, AACC, St Paul, MN.

AOAC, (2005). Association of Official Analytical Chemists. Official Methods of Analysis. $18^{\text {th }}$ Ed. Published by AOAC. W. Horwitz. North Frederick, U.S.A.

Autio, K.; L. Flander; A. Kinnunen, and R. Heininen (2001). Bread quality relationship with rheological measurements of wheat flour dough. Cereal Chern. 78: 654-657.

Charles Fahrenholz (2005). Cereal grains and byproducts: What's in them and how are they processed ? Cereal Grains and Byproducts page 5770.

D'Appolonia B. L. and Emeritus, (1996). How Flour Affects Bread Quality Department of Cereal Science, North Dakota State University, Fargo, ND 58105, Lallemand Baking Update, vol.1 / No. 17.

ES, (1986). Egyptian Standard of wheat grains. Egyptian Organization for Standardization and Quality Control, No. 1601, and its modification No. 2/2002. Arab Republic of Egypt.

ES, (2004). Egyptian Standard of durum wheat. Egyptian Organization for Standardization and Quality Control, No. 1649. Arab Republic of Egypt.

ES, (2006). Egyptian Standard of white flour for production of bread. Egyptian Organization for Standardization and Quality Control, No. 1419. Arab Republic of Egypt.

FAO, (2005). Food and Agriculture Organization. FAO Statistics Database. Accessed on: Feb. 14, 2005; Available at: http:// a pps.fao.org/faostatl. 
Grausgruber, H., Oberforster, M., Werteker, M., Ruckenbauer, J. \& Vollmann, J., (2000). Stability of quality traits in Austrian-grown winter wheats. Field Crop Research 66, 257-267.

Gupta RK, Sewa Ram and Chauhan DS, (2002). Quality of Indian wheat. Directorate of Wheat Research, Karnal - 132001. Research Bulletin No. 14

Hamza, A.H. (2003) American wheat standards: The reliable assurance for quality wheat foods, pp. 20-21. Food Additives \& Cereal Fortification Conf., 13-16 Sep. 2003, Cairo, Egypt.

Katarina V. Mirić and Dušanka J. Pejin, (2008). Effects of mill stream flours technological quality on fermentative activity of baker's yeast Saccharomyces cerevisiae. University of Novi Sad, Faculty of Technology, Original scientific paper BIBLID: 1450-7188,39, 153-159.

Kun-Pu Zhang, Guang-Feng Chen, Liang Zhao, Bin Liu, Xian-Bin Xu and JiChun Tian, (2009). Molecular genetic analysis of flour color using a doubled haploid population in bread wheat (Triticum aestivum L.) Springer Science, Euphytica 165:471-484.

Mahmood, A., (2004). Acid-PAGE gliadin composition and cluster analysis for quality traits for different wheat varieties. Ph.D. Thesis, Dept. Food Technol. Univ. Agric. Faisalabad.

Milatovie, L. and Mondelli, G., (1991). Pasta Technology Today. Ed. by ChiriottiPoinerolo (To) - Italy.

Nagarajan S., (2005). Quality Characteristics of Indian Wheat, Quality and basic sciences, Vol. 4. Issue 9, Pages 79-86.

Pasha, I., (2006). Biochemical characterization of Pakistani wheats in relation to grain hardness. Ph.D. Thesis, Dept. Food Technol. Univ. Agric. Faisalabad.

Peressini, D.; A. Sensidoni; C.M. Pollini and B. De Cindio, (1999). Improvement of wheat fresh pasta-making quality: influence of sodium chloride on dough rheological properties. Italian Food \& Beverage Tech. 17: 20-23,33.

Randhawa, M.A., F.M. Anjum and M.S. Butt, (2002). Physico-chemical and milling properties of new spring wheats grown in Punjab and Sind for the production of pizza. Int. J. Agric. Biol., 4: 482-484.

SAS, (1999). SAS / Stat. User's Guide: statistics, system for windows, version 4.10 (releasa 6.12 TS level 0020), SAS Inst., Inc. Cary, North Carolina, USA.

U.S. Department of Agriculture, (1995 A). Grain Inspection Handbook I. Grain Inspection, Packers and Stockyards Administration ,Federal Grain Inspection Service Probe Sampling, Washington, D.C. 20090-6454.

U.S. Department of Agriculture, (1999 B). Moisture Handbook Grain Inspection, Packers and Stockyards Administration 1400 Independence Ave., S. W. Washington, D.C. 20250-3600.

U.S. Department of Agriculture, (2002 C). Equipment Handbook. Grain Inspection, Packers and Stockyards Administration, 1400 Independence Ave., S.W. Washington, D.C. 20250-3600. 


\section{Abd El Fadel, M.G. et al.}

U.S. Department of Agriculture, (2006 D). Grain inspection Handbook II Grain Inspection, Packers and Stockyards Administration, Federal Grain Inspection Service.

تأثير عمليات التداول والطدن والتخزين علي جودة القمح والدقيق في مصر:

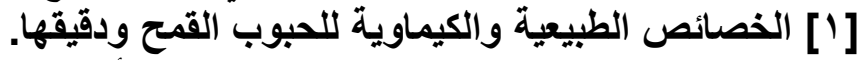

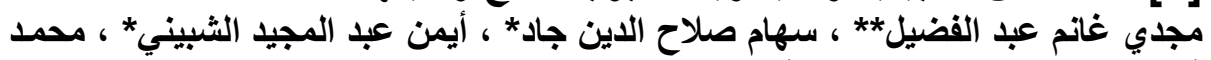

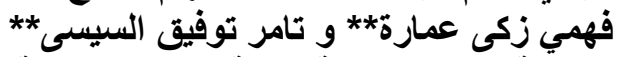

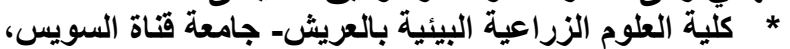

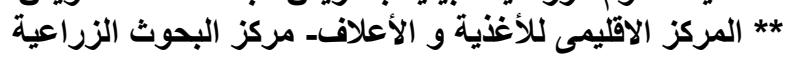

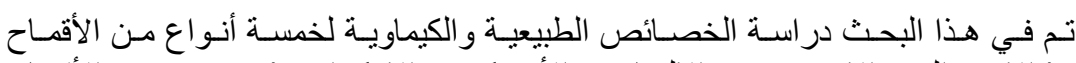

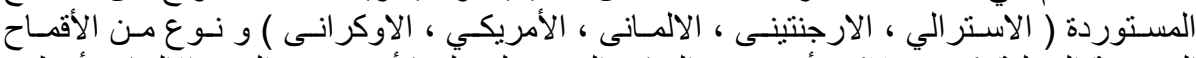

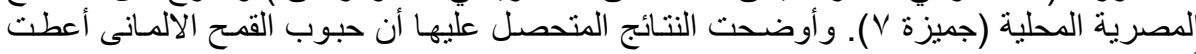

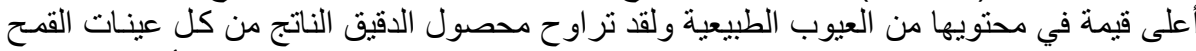

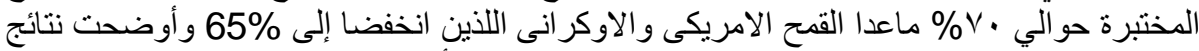

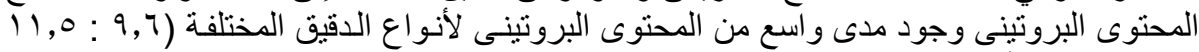

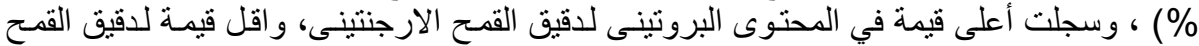

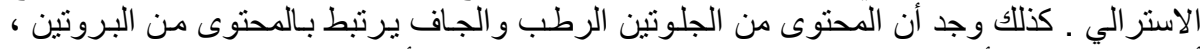

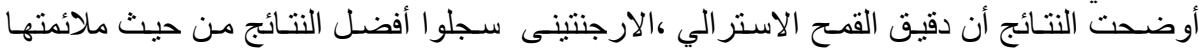

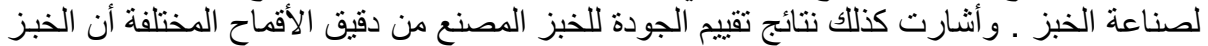
المصنع من دقيق القمح الارجنتينى ، الاستر الي كانت ممتازة .

كلية الزراعة - جامعة المنصورة

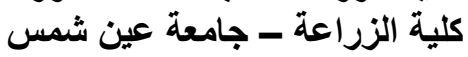

قام بتحكيم البحث

أ. أد / مسعد عبد اليحزيز العزيز ابو ريه أ.د / احمد يوسف جبريل 